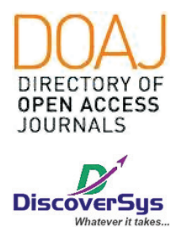

Published by DiscoverSys

\section{Karakteristik anak yang mengalami child abuse dan neglect di RSUP Sanglah, Denpasar, Indonesia tahun 2015-2017}

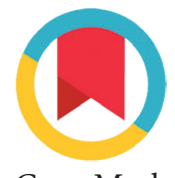

CrossMark

\author{
Made Ardinata, ${ }^{1 *}$ Soetjiningsih, ${ }^{1}$ I Gusti Ayu Trisna Windiani, ${ }^{1}$ \\ I Gusti Agung Ngurah Sugitha Adnyana, ${ }^{1}$ Ida Bagus Putu Alit ${ }^{2}$
}

\title{
ABSTRACT
}

Background: Child abuse and neglect is any form of physical, emotional, sexual abuse, or neglect of children. Child abuse causes various consequences that are harmful to the child and the future of the nation. The purpose of this study was to determine the characteristics of children who experience child abuse at Sanglah Hospital Denpasar. Methods: A cross sectional study design was conducted using secondary data taken from medical records of the Forensic Medicine Department, Sanglah General Hospital Denpasar from January 2015 to December 2017. Data related to age, gender, origin, types of abuse, and perpetrator's house were analyzed as percentage using SPSS version 17 software. Ethical clearance was carried out prior study conducted.

Result: From 2015 to 2017, 173 subjects were recorded as child abuse. The age group of 13-15 years and 16-18 years is the highest age group that experiences child abuse which is $28.3 \%$ and $33.5 \%$. Subjects of female sex were $56.0 \%$. The highest distribution of subject origin comes from Denpasar area $20.8 \%$ and the highest education level of parents is $45.0 \%$ senior high school. Subjects who experienced physical violence and threats were $93.6 \%$, sexual violence was $50.8 \%$, and $1.7 \%$ experienced neglect. The perpetrators of child abuse are mostly people who are known to the victim. The perpetrator's or subject's house is the place where most physical, emotional, or sexual violence occurs, which is $72.2 \%, 69.7 \%$, and $89.7 \%$ respectively.

Conclutions: Most cases of Child abuse occur in the age group of 13-15 years and 16-18 years. Child abuse is more common in women; most of the perpetrators are people who are recognized. Home is the most common place of physical, emotional, or sexual violence.

Keyword: children, characteristic, child abuse

Cite This Article: Ardinata, M., Soetjiningsih,Windiani, I.G.A.T., Adnyana, I.G.A.N.S., Alit, I.B.P. 2019. Karakteristik anak yang mengalami child abuse dan neglect di RSUP Sanglah, Denpasar, Indonesia tahun 2015-2017. Intisari Sains Medis 10(2): 436-441. D0I: 10.15562/ism.v10i2.404

ABSTRAK

Latar Belakang: Child abuse dan neglect adalah segala bentuk penyiksaan fisik, emosional, pelecehan seksual, atau kelalaian terhadap anak. Child abuse menimbulkan berbagai akibat yang berbahaya bagi anak maupun masa depan bangsa. Tujuan penelitian ini adalah untuk mengetahui karakteristik anak-anak yang mengalami child abuse dan neglect di RSUP Sanglah Denpasar.

Metode: Penelitian ini menggunakan rancangan penelitian cross sectional, data diambil dari rekam medis Departemen Kedokteran Forensik RSUP Sanglah Denpasar dari Januari 2015 hingga Desember 2017. Data yang berhubungan dengan usia, jenis kelamin, asal, jenis abuse, dan rumah pelaku dianalisis secara persentase menggunakan piranti lunak SPSS versi 17. Persetujuan etik telah diperoleh sebelum penelitian berjalan.

Hasil: Selama periode waktu 2015 hingga 2017 terdapat 173 subjek yang tercatat mengalami child abuse. Kelompok usia 13-15 tahun dan
16-18 tahun merupakan kelompok usia terbanyak yang mengalami child abuse yakni $28,3 \%$ dan 33,5\%. Subjek berjenis kelamin perempuan sebanyak $56,0 \%$. Distribusi asal subjek terbanyak berasal dari wilayah Denpasar 20,8\% dan tingkat pendidikan tertinggi orangtua adalah SMA $45,0 \%$. Subjek yang mengalami kekerasan fisik dan ancaman sebanyak 93,6\%, kekerasan seksual 50,8\% serta $1,7 \%$ mengalami penelantaran. Pelaku child abuse sebagian besar merupakan orang yang dikenal oleh korban. Rumah pelaku atau subjek adalah tempat terbanyak terjadinya kekerasan fisik, emosional, maupun seksual yakni secara urut sebesar $72,2 \%, 69,7 \%$ dan $89,7 \%$.

Simpulan: Child abuse terbanyak pada kelompok usia 13-15 tahun dan 16-18 tahun. Child abuse lebih sering terjadi pada perempuan, sebagian besar pelaku merupakan orang yang dikenali. Rumah merupakan tempat paling sering terjadinya kekerasan fisik, emosional, maupun seksual.
Kedokteran, Universitas Udayana/

RSUP Sanglah Denpasar;

madeardinata87@gmail.com

Diterima: 08-01-2019

Disetujui: 24-05-2019

Diterbitkan: 01-08-2019
Kata kunci: anak, karakteristik, child abuse

Cite Pasal Ini: Ardinata, M., Soetjiningsih,Windiani, I.G.A.T., Adnyana, I.G.A.N.S., Alit, I.B.P. 2019. Karakteristik anak yang mengalami child abuse dan neglect di RSUP Sanglah, Denpasar, Indonesia tahun 2015-2017. Intisari Sains Medis 10(2): 436-441. D0I: 10.15562/ism.v10i2.404 


\section{PENDAHULUAN}

Anak adalah aset suatu bangsa. Anak yang berusia kurang dari 18 tahun termasuk yang berada dalam kandungan merupakan definisi anak berdasarkan undang-undang tentang perlindugan anak no 23 tahun 2002 tentang perlindungan anak. ${ }^{1}$ Child abuse adalah segala bentuk penyiksaan fisik, emosional, pelecehan seksual, atau kelalaian terhadap anak. Child abuse akan menimbulkan berbagai akibat yang berbahaya bagi anak itu sendiri maupun masa depan bangsa.

Child abuse didefinisikan sebagai suatu perbuatan disengaja yang dapat menimbulkan kerugian atau bahaya terhadap anak-anak secara fisik ataupun emosional. 1stilah child abuse dapat mencakup berbagai macam bentuk tingkah laku, dari tindakkan ancaman fisik secara langsung oleh orangtua atau orang dewasa lainnya sampai dengan penelantaran kebutuhan-kebutuhan dasar anak. ${ }^{2}$

Child abuse dilaporkan terjadi hampir di seluruh dunia dengan prevalens yang cenderung meningkat dari tahun ke tahun. Sebuah studi memperkirakan 25 hingga 50 persen anak di seluruh dunia mengalami kekerasan fisik, dan sekitar 20 persen wanita serta 5 hingga 10 persen lelaki mengalami kekerasan sexual. ${ }^{3}$ Angka kejadian child abuse di Amerika Serikat mencapai angka 295.000 kasus pada tahun 2013 dan meningkat hingga 315.000 kasus pada tahun 2014. Berdasarkan data the National Child Abuse and Neglect Data System (NCANDS), pada tahun 2014 sebanyak 50 negara di dunia melaporkan angka kejadian child abuse sebanyak 1.546 korban jiwa. Berdasarkan data tersebut, secara umum pada tahun 2014 angka kejadian child abuse mencapai 2,13 anak per 100.000 anak dan rata-rata empat anak meninggal setiap hari karena child abuse di seluruh dunia. ${ }^{4}$ Tindak kekerasan terhadap anak atau child abuse di Indonesia sendiri, telah dilaporkan terjadi hampir merata dari Sabang hingga Merauke. Berdasarkan hasil survey oleh Kementrian Sosial, dan Kementrian Pemberdayaan Perempuan dan Perlindungan Anak, dicatat sejumlah 7.061.946 anak atau diperkirakan 1 dari 3 anak lelaki mengalami kekerasan fisik,emosional, maupun sexual. Jumlah perempuan yang mengalami kejadian serupa dicatat sejumlah 2.603 .770 anak, atau diperkirakan 1 dari 2 anak perempuan mengalami kekerasan. $^{5}$

Child abuse meliputi physical abuse (kekerasan fisik), sexual abuse (Kekerasan seksual), emotional abuse (Kekerasan Emosional), Neglect (Penelantaran). ${ }^{6}$ Efek child abuse dapat berdampak pada perubahan fisik dan perilaku seorang anak. Perubahan fisik dapat diakibatkan dari kekerasan fisik (memukul, menggigit, mencekik dan lain sebagainya) yang mengakibatkan luka, kebiruan, trauma fisik yang nyata. Dampak perilaku emosional dan kesulitan berdaptasi dengan lingkungan merupakan salah satu wujud nyata dari efek jangka panjang child abuse. ${ }^{7}$

Data kejadian child abuse di Bali masih sangat terbatas dan selama ini laporan yang ada hanya dalam bentuk administratif. Berdasarkan hal tersebut, tujuan penelitian ini adalah untuk mengetahui karakteristik child Abuse dan neglect di Provinsi Bali sejak tahun 2015 hingga tahun 2017 dimana dapat dipergunakan sebagai studi awal dalam upaya penanganannya di kemudian hari.

\section{METODE}

Penelitian ini menggunakan rancangan penelitian potong lintang yang dilakukan dengan cara mengambil data yang bersifat sekunder dari laporan kasus kekerasan anak Departemen Kedokteran Forensik RSUP Sanglah Denpasar dari Januari 2015 sampai Desember 2017 yang didapat dari catatan medis pasien. Penelitian dilakukan dibagian Departemen Kedokteran Forensik RSUP Sanglah Denpasar. Penelitian dilakukan dari Agustus sampai Desember 2017. Populasi target pada penelitian ini adalah semua anak yang mengalami child abuse. Populasi terjangkau pada penelitian ini adalah semua anak dengan child abuse yang tercatat dalam laporan kasus Departemen Kedokteran Forensik RSUP Sanglah Denpasar dari Januari 2015 sampai Desember 2017. Subjek penelitian adalah semua kasus child abuse yang dilaporkan dan tercatat yang diambil dari laporan kasus kekerasan anak Departemen Kedokteran Forensik RSUP Sanglah Denpasar dari Januari 2015 sampai Desember 2017. Kriteria inklusi adalah semua anak dengan child abuse yang memiliki laporan dan catatan lengkap dalam laporan kasus dari Januari 2015 sampai Desember 2017. Kriteria eksklusi adalah data tidak lengkap.

Child abuse adalah segala suatu perbuatan disengaja yang dapat menimbulkan kerugian atau bahaya terhadap anak-anak dalam bentuk penyiksaan fisik, emosional, pelecehan seksual, atau kelalaian terhadap anak. lstilah child abuse dapat mencakup berbagai macam bentuk tingkah laku, dari tindakan ancaman fisik secara langsung oleh orangtua atau orang dewasa lainnya sampai dengan penelantaran kebutuhan dasar anak. ${ }^{2}$ Menurut Undang-Undang Republik Indonesia Nomor 35 tahun 2014 tentang perlindungan anak, pasal 1 ayat 1: "Anak adalah seseorang yang belum berusia 18 (delapan belas) tahun, termasuk anak yang masih dalam kandungan". 
Kelompok usia anak dibagi menjadi, kelompok usia $<6$ tahun, kelompok usia 6-12 tahun, kelompok usia 13-15 tahun dan kelompok usia 16-18 tahun. Jenis kelamin adalah jenis kelamin dari subjek yang mengalami child abuse. Kabupaten/kota asal adalah tempat dimana subjek berasal yang tercatat pada rekam medis subjek. Pendidikan orangtua diambil berdasarkan tingkat akademis pendidikan tertinggi dari salah satu orangtua berdasarkan hasil laporan kasus. Jenis kekerasan yang dialami dibagi berdasarkan riwayat kekerasan yang dialami yang didapatkan dari catatan laporan child abuse kekerasan fisik (bila didapatkan hasil visum luka atau jejas terhadap bagian tubuh, baik dengan senjata tajam,benda tumpul, dan lain sebagainya), kekerasan emosional (termasuk didalamnya bila didapatkan laporan kasus pengancaman, pembullyan, dan lain sebagainya), kekerasan seksual (dibuktikan dari hasil visum), negletc (termasuk didalamnya segala bentuk penelantaran terhadap anak). Hubungan pelaku-korban dibagi menjadi pelaku adalah orang yang dikenal korban, dan pelaku adalah orang yang tidak dikenal oleh korban. Lokasi kejadian merupakan tempat terjadinya kasus child abuse yang dibedakan menjadi di dalam lingkungan rumah (subjek atau pelaku)dan di luar lingkungan rumah (sekolah, jalan, kantin, dll).

Penelitian ini sudah mendapatkan persetujuan dari komite etik penelitian (KEP) Fakultas Kedokteran Universitas Udayana/Rumah Sakit Umum Pusat Sanglah Denpasar nomor EC 2017.02.1.1307. Data yang diperoleh kemudian ditabulasi dan dianalisis menggunakan piranti lunak SPSS versi 17 untuk Windows.

\section{HASIL}

Hasil penelitian selama periode waktu Januari 2015 hingga Desember 2017 terdapat 173 subjek yang tercatat mengalami child abuse di Kedokteran Forensik RSUP Sanglah Denpasar pada tahun 2015-2017, dan memenuhi kriteria inklusi. Subjek dengan kelompok usia $<6$ tahun sebanyak $16,7 \%$, 6-12 tahun sebanyak 21,3\%, usia 13-15 tahun sebanyak $28,3 \%$ dan usia 16-18 tahun sebanyak $33,5 \%$. Subjek child abuse dapat terjadi pada wanita maupun lelaki, dimana selama periode penelitian didapatkan subjek berjenis kelamin perempuan sebanyak 97 orang $(56,0 \%)$, dan lelaki sebesar 76 (43,9\%). Subjek child abuse berasal dari seluruh kabupaten yang ada di Provinsi Bali dimana subjek yang berasal dari kabupaten Denpasar terdapat 36 kasus (20,8\%), Badung 31 kasus $(17,9 \%)$, Tabanan 18 kasus (10,4\%), Karangasem 12 kasus (6,9\%), Klungkung 9 kasus (5,2\%), Bangli 16 kasus (9,2\%), Buleleng 21 kasus (12,1\% kasus) dan Jembrana terdapat 23 kasus $(13,2 \%)$. Tingkat pendidikan orangtua subjek child abuse berasal dari berbagai tingkat pendidikan, dimana tingkat pendidikan terbanyak orangtua subjek adalah SMU 78 orang $(45,0 \%)$, diikuti dengan diploma/sarjana 69 orang (39,8\%), SMP 17 orang $(9,8 \%)$, SD 6 orang $(3,4 \%)$, dan tidak bersekolah 3 orang $(1,7 \%)$. Jenis kekerasan yang dialami subjek terbanyak adalah kekerasan fisik, baik dengan benda tumpul 90,1\% kasus (tangan, kaki, kayu, besi dll) maupun benda tajam 3,4\% kasus (penusukan, perkelahian dengan senjata tajam). Kekerasan emosional sering kali menyertai berbagai tindakan child abuse yang terjadi, 162 kasus (93,6\%) subjek mendapatkan ancaman dari pelaku dan hanya 11 kasus $(6,3 \%)$ tidak disetai ancaman ataupun kekerasan, dimana 8 dari 11 kasus tersebut terjadi saat subjek tidak

\section{Tabel 1 Karakteristik subjek dengan riwayat Child Abuse}

\begin{tabular}{|c|c|}
\hline Variabel & $\begin{array}{c}N=173 \\
(\%)\end{array}$ \\
\hline \multicolumn{2}{|l|}{ Umur (Tahun), n (\%) } \\
\hline$<6$ Tahun & $29(16,7)$ \\
\hline 6-12 Tahun & $37(21,3)$ \\
\hline 13-15 tahun & $49(28,3)$ \\
\hline 16-18 tahun & $58(33,5)$ \\
\hline \multicolumn{2}{|l|}{ Jenis kelamin, $\mathbf{n}(\%)$} \\
\hline Lelaki & $76(43,9)$ \\
\hline Perempuan & $97(56,0)$ \\
\hline \multicolumn{2}{|l|}{ Kabupaten/kota, n (\%) } \\
\hline Denpasar & $36(20,8)$ \\
\hline Badung & $31(17,9)$ \\
\hline Tabanan & $18(10,4)$ \\
\hline Karangasem & $12(6,9)$ \\
\hline Klungkung & $9(5,2)$ \\
\hline Bangli & $16(9,2)$ \\
\hline Buleleng & $21(12,1)$ \\
\hline Jembrana & $23(13,2)$ \\
\hline Gianyar & $9(5,2)$ \\
\hline \multicolumn{2}{|c|}{ Pendidikan Orangtua, n (\%) } \\
\hline Tidak Bersekolah & $3(1,7)$ \\
\hline SD & $6(3,4)$ \\
\hline SMP & $17(9,8)$ \\
\hline SMA & $78(45,0)$ \\
\hline Diploma/sarjana & $69(39,8)$ \\
\hline \multicolumn{2}{|c|}{ Kekerasan yang dialami, n(\%) } \\
\hline Kekerasan fisik & $162(93,6)$ \\
\hline Kekerasan emosional & $162(93,6)$ \\
\hline Kekerasan seksual & $88(50,8)$ \\
\hline Penelantaran, n (\%) & $3(1,7)$ \\
\hline
\end{tabular}


Tabel 2 Karakteristik subjek berdasarkan hubungan dengan pelaku

\begin{tabular}{lcccc}
\hline Kejadian Child Abuse & $\begin{array}{c}\text { Kekerasan Fisik } \\
(\mathbf{N}=\mathbf{1 6 2})\end{array}$ & $\begin{array}{c}\text { Kekerasan } \\
\text { Emosional } \\
(\mathbf{N}=162)\end{array}$ & $\begin{array}{c}\text { Kekerasan } \\
\text { Seksual } \\
(\mathbf{N}=\mathbf{8 8})\end{array}$ & $\begin{array}{c}\text { Penelantaran } \\
(\mathbf{N}=\mathbf{3})\end{array}$ \\
\hline Orang yang dikenal (n,\%) & $114(70.3)$ & $126(77,7)$ & $74(84.0)$ & $3(100)$ \\
Orang tidak dikenal (n,\%) & $48(29.6)$ & $36(22,2)$ & $14(15.9)$ & $0(0)$ \\
\hline
\end{tabular}

Tabel 3 Karakteristik jenis child abuse berdasarkan lokasi kejadian

\begin{tabular}{lcccc}
\hline Kejadian Child Abuse & $\begin{array}{c}\text { Kekerasan Fisik } \\
(\mathbf{N}=\mathbf{1 6 2})\end{array}$ & $\begin{array}{c}\text { Kekerasan Emosional } \\
(\mathbf{N}=\mathbf{1 6 2})\end{array}$ & $\begin{array}{c}\text { Kekerasan Seksual } \\
(\mathbf{N}=\mathbf{8 8})\end{array}$ & $\begin{array}{c}\text { Penelantaran } \\
(\mathbf{N}=\mathbf{3})\end{array}$ \\
\hline Rumah (n,\%) & $117(72,2)$ & $113(69,7)$ & $79(89,7)$ & $0(0)$ \\
Di luar rumah (n,\%) & $45(27,7)$ & $49(30,2)$ & $9(10,2)$ & $3(100)$ \\
\hline
\end{tabular}

sadar atau mabuk. Kekerasan seksual terjadi pada 88 subjek (50,8\%) dari seluruh kasus yang tercatat selama januari 2015 hingga Desember 2018, dimana jenis kekerasan yang terjadi adalah 59 kasus $(67,0 \%)$ penetrasi, dan 29 kasus $(32,9 \%)$ adalah kontak pada daerah seksual subjek. Selama kurun waktu penelitian, tercatat 3 kasus penelantaran yang terjadi (pembuangan bayi). Karakteristik subjek secara jelas dapat dilihat seperti pada Tabel 1 .

Subjek child abuse yang mengalami kekerasan fisik berjumlah 162 orang, dimana 114 orang $(70,3 \%)$ pelaku merupakan orang yang dikenal subjek dan 48 orang $(29,6 \%)$ pelaku tidak dikenal oleh subjek. Kekerasan emosional yang tercatat pada 162 anak yang mengalami child abuse dimana 126 subjek $(77,7 \%)$ pelaku adalah orang yang dikenal subjek dan hanya 36 orang $(22,2 \%)$ pelaku yang tidak dikenal subjek. Kekerasan Seksual tercatat sebanyak 88 orang selama periode waktu penelitian, dimana 74 orang $(84,0 \%)$ subjek mengenali pelaku child abuse dan hanya 14 orang $(15,9 \%)$ subjek yang tidak mengenali pelaku. Terdapat 3 kasus penelantaran yang tercatat selama tahun 2015 hingga 2017 dan $100 \%$ pelaku adalah orangtua subjek (Tabel 2.).

Kejadian child abuse dapat terjadi dimana saja. Subjek yang mengalami kekerasan fisik berjumlah 162 orang, dimana tempat kejadian 117 orang $(72,2 \%)$ adalah tempat tinggal subjek atau pelaku dan 45 orang $(27,7 \%)$ terjadi diluar rumah subjek atau pelaku. Kekerasan emosional yang tercatat pada 162 anak yang mengalami child abuse dimana tempat kejadian 113 subjek (69,7\%) pelaku adalah tempat tinggal subjek atau pelaku dan hanya 49 orang $(30,2 \%)$ terjadi diluar rumah subjek atau pelaku. Kekerasan Seksual tercatat sebanyak 88 orang selama periode waktu penelitian, dimana tempat kejadian 79 orang $(89,7 \%)$ subjek adalah tempat tinggal subjek atau pelaku child abuse dan hanya 9 orang $(10,2 \%)$ terjadi di luar rumah subjek atau pelaku.. Tiga kasus penelantaran yang tercatat selama tahun 2015 hingga 2017 dan 100\% tempat terjadinya adalah diluar tempat tinggal subjek ataupun pelaku (Tabel 3).

\section{PEMBAHASAN}

Penelitian mengambil data yang berasal dari catatan medis dan visum laporan kasus kekerasan anak Departemen Kedokteran Forensik RSUP Sanglah Denpasar dari Januari 2015 sampai Desember 2017. Berdasarkan umur, selama periode penelitian didapatkan subjek child abuse dengan kelompok usia $<6$ tahun sebanyak $16,7 \%$, 6-12 tahun sebanyak 21,3\%, usia 13-15 tahun sebanyak $28,3 \%$ dan usia 16-18 tahun sebanyak 33,5\%. Hasil penelitian di india (Ministry of Women and Child Development Government of India, 2007) didapatkan distribusi usia anak yang mengalami child abuse telah dimulai pada usia $<5$ tahun, kemudian mengalami peningkatan pada usia 10 tahun, dan mencapai puncak pada usia 12 hingga 15 tahun. ${ }^{8}$ Data tersebut hampir sama dengan data yang diperoleh selama periode waktu penelitian di Departemen Kedokteran Forensik RSUP Sanglah. Peningkatan kasus pada anak usia belasan tahun menunjukkan kerentanan terjadinya tindak child abuse pada anak.

Berdasarkan jenis kelamin subjek child abuse dapat terjadi pada wanita maupun lelaki. Selama periode penelitian didapatkan subjek berjenis kelamin perempuan sebanyak 97 orang $(56,0 \%)$, dan lelaki sebesar 76 (43,9\%). Sebuah studi memperkirakan 25 hingga 50 persen anak di seluruh dunia mengalami kekerasan fisik, dan seki$\operatorname{tar} 20$ persen wanita serta 5 hingga 10 persen lelaki mengalami kekerasan seksual. Berdasarkan hasil survey oleh Kementerian Sosial, dan Kementerian Pemberdayaan Perempuan dan Perlindungan Anak, dicatat sejumlah 7.061.946 anak atau diperkirakan 1 dari 3 anak lelaki mengalami 
kekerasan fisik,emosional, maupun sexual. Jumlah perempuan yang mengalami kejadian serupa dicatat sejumlah 2.603.770 anak, atau diperkirakan 1 dari 2 anak perempuan mengalami kekerasan., ${ }^{5,8}$ Hal ini memiliki kemiripan dengan hasil penelitian ini dimana jenis kelamin perempuan memiliki kecenderugan lebih besar terhadap kejadian child abuse dibandingkan dengan lelaki.

Distribusi subjek berasal dari seluruh kabupaten yang ada di Provinsi Bali dimana subjek terbanyak berasal dari kabupaten Denpasar terdapat 36 kasus $(20,8 \%)$, selanjutnya kabupaten Badung 31 kasus (17,9\%), Jembrana terdapat 23 kasus $(13,2 \%)$, Buleleng 21 kasus (12,1\% kasus), Tabanan 18 kasus $(10,4 \%)$, Bangli 16 kasus (9,2\%), Karangasem 12 kasus (6,9\%), Gianyar 9 kasus (5,2\%) dan Klungkung 9 kasus (5,2\%). Hal ini sesuai dengan gambaran distribusi child abuse di Indonesia yang terjadi hampir merata dari Sabang sampai Merauke. $^{5}$

Tingkat pendidikan masyarakat di negara maju tidak mencerminkan terhadap penurunan jumlah tindak child abuse yang terjadi pada masyarakat. Berdasarkan data dari the National Child Abuse and Neglect Data System (NCANDS), pada tahun 2014 sebanyak 50 negara di dunia dengan tingkat pendidikan yang maju, melaporkan angka kejadian akibat child abuse sebanyak 1.546 subjek jiwa. Berdasarkan data tersebut, secara umum pada tahun 2014 angka kejadian child abuse mencapai 2,13 anak per 100.000 anak dan rata-rata empat anak meninggal setiap hari karena child abuse di seluruh dunia. ${ }^{3}$ Pendidikan terbanyak orangtua subjek child abuse yang tercatat selama periode penelitian adalah SMU 78 orang $(45,0 \%)$, diikuti dengan diploma/ sarjana 69 orang $(39,8 \%)$, SMP 17 orang $(9,8 \%)$, SD 6 orang $(3,4 \%)$, dan tidak bersekolah 3 orang $(1,7 \%)$. Hasil penelitian ini serupa dengan yang diungkapkan oleh Caroline Day, dimana tingginya tingkat pendidikan tidak memengaruhi penurunan tingkat kekerasan terhadap anak atau child abuse. ${ }^{3}$

Klasifikasi utama dari child abuse meliputi physical abuse (kekerasan fisik), sexual abuse (Kekerasan seksual), emotional abuse (Kekerasan Emosional), neglect (Penelantaran). Selama kurun waktu penelitian didapatkan Jenis kekerasan yang dialami subjek terbanyak adalah kekerasan fisik, baik dengan benda tumpul 90,1\% kasus (tangan, kaki, kayu, besi dll) maupun benda tajam 3,4\% kasus (penusukan, perkelahian dengan senjata tajam). Kekerasan emosional sering kali menyertai berbagai tindakan child abuse yang terjadi, 162 kasus $(93,6 \%)$ subjek mendapatkan ancaman dari pelaku dan hanya 11 kasus (6,3\%) tidak disetai ancaman ataupun kekerasan, dimana 8 dari 11 kasus tersebut terjadi saat subjek tidak sadar atau mabuk. Kekerasan seksual terjadi pada 88 subjek $(50,8 \%)$ dari seluruh kasus yang tercatat selama januari 2015 hingga Desember 2018, dimana jenis kekerasan yang terjadi adalah 59 kasus $(67,0 \%)$ penetrasi, dan 29 kasus (32,9\%) adalah kontak pada daerah seksual subjek. Selama kurun waktu penelitian, tercatat 3 kasus penelantaran (pembuangan bayi) yang terjadi. Hasil dari penelitian ini sedikit berbeda dari laporan yang didapatkan pada beberapa penelitian, dimana pada negara maju jenis child abuse yang didapatkan lebih dari $64,1 \%$ mengalami penelantaran, $14 \%$ mengalami kekerasan fisik, 8,8\% mengalami kekerasan seksual, dan 6,6\% mengalami kekerasan emosional. ${ }^{9}$ Perbedaan ini dapat terjadi akibat jumlah subjek yang diambil hanya berdasarkan hasil laporan dan visum medis terbatas hanya pada rumah sakit sanglah denpasar.

Tindakan child abuse dapat dilakukan oleh siapa saja, pada penelitian ini mencatat subjek child abuse yang mengalami kekerasan fisik berjumlah 162 orang, dimana 114 orang (70,3\%) pelaku merupakan orang yang dikenal subjek dan 48 orang $(29,6 \%)$ pelaku tidak dikenal oleh subjek. Kekerasan emosional yang tercatat pada 162 anak yang mengalami child abuse dimana 126 subjek $(77,7 \%)$ pelaku adalah orang yang dikenal subjek dan hanya 36 orang $(22,2 \%)$ pelaku yang tidak dikenal subjek. Kekerasan Seksual tercatat sebanyak 88 orang selama periode waktu penelitian, dimana 74 orang $(84,0 \%)$ subjek mengenali pelaku child abuse dan hanya 14 orang $(15,9 \%)$ subjek yang tidak mengenali pelaku. Kasus penelantaran yang tercatat selama tahun 2015 hingga 2017 sebanyak 3 orang dan $100 \%$ pelaku adalah orangtua subjek. Hal ini serupa dengan penelitian lain dimana anak yang mengalami kekerasan fisik, kekerasan seksual, kekerasan emosional, dan penelantaran menunjukan bahwa hampir $80 \%$ pelaku merupakan orang yang memiliki hubungan dengan subjek (dikenali oleh subjek). ${ }^{10,11}$

Tempat kejadian child abuse dapat terjadi dimana saja. Subjek yang mengalami kekerasan fisik (72,2\%), kekerasan emosional (69,7\%), kekerasan seksual $(89,7 \%)$ dan penelantaran yang tercatat selama tahun 2015 hingga 2017 sebagian besar tempat kejadian adalah di dalam tempat tinggal pelaku ataupun subjek (rumah atau kos). Hanya sebagian kecil tindakan child abuse yang terjadi di luar tempat tinggal subjek ataupun pelaku (sekolah, jalan, hotel, dll). Hal ini serupa dengan penelitian lain yang menyatakan bahwa kejadian kekerasan terhadap anak dimulai dari lingkungan tempat tinggal subjek itu sendiri dimana pelaku tindakan child abuse sebagian besar tinggal bersama dengan subjek. ${ }^{12}$

Limitasi dari penelitian ini adalah sampel merupakan pasien yang pernah dirawat di RSUP 
Sanglah Denpasar, sehingga tidak dapat menggambarkan besarnya kejadian child abuse yang terjadi di masyarakat. Data diambil berdasarkan data sekunder dari rekam medis, sehingga peneliti hanya bisa mencatat apa yang ada dalam rekam medis dan visum subjek. Penelitian lebih lanjut dengan tempat dan waktu yang berbeda diperlukan untuk membandingkan besarnya kejadian child abuse yang terjadi.

Child abuse terbanyak pada kelompok usia 13-15 tahun dan 16-18 tahun. Child abuse lebih sering terjadi pada perempuan, sebagian besar pelaku merupakan orang yang dikenali. Rumah merupakan tempat paling sering terjadinya kekerasan fisik, emosional, maupun seksual.

\section{ETIKA PENELITIAN}

Persetujuan etik telah diperoleh oleh komisi etik Fakultas Kedokteran Universitas Udayana, RSUP Sanglah, Denpasar, Indonesia sebelum studi dijalankan.

\section{KONFLIK KEPENTINGAN}

Tidak terdapat konflik kepentingan dalam pembuatan laporan penelitian pada artikel ini.

\section{PENDANAAN}

Penulis bertanggung jawab terhadap pendanaan studi ini tanpa melibatkan pihak sponsor, grant, atau berbagai sumber pendanaan.

\section{KONTRIBUSI PENULIS}

Seluruh penulis berkontribusi terhadap penyusunan laporan penelitian ini dari tahap usulan proposal, pengumpulan data, analisis data, hingga sintesis laporan akhir penelitian.

\section{DAFTAR PUSTAKA}

1. Sudibyo E. Undang-undang Republik Indonesia Nomor 23 Tahun 2002 tentang Perlindungan Anak. Lembaga Negara Republik Indonesia. 2002; 109: 1-14.

2. Soetjiningsih, Ranuh IGN. Tumbuh kembang anak: perlakuan salah pada anak (child abuse). Buku Kedokteran EGC: Jakarta. 2012.

3. Day C, Hibbert P, Cadman S. A Literature Review into Children Abused and/or Neglected Prior Custody. Youth justice board. 2008: 1-69.

4. Covington, T. The public health approach for understanding and preventing child maltreatment: A brief review of the literature and a call to action. Child Welfare. 2013; 92(2), 21-40.

5. Kurniasari A, Wismaayanti Y, Irmayani,Husmiati, Widodo N, Susantyo B. Survey Kekerasan Terhadap Anak Indonesia Tahun 2013. Kementerian Pemberdayaan Perempuan dan Perlindungan Anak. 2013:1-13

6. Finkelhor D. An International Congress on Child Abuse and Neglect. Crimes Against Children Research Center. 2012:1-13

7. Douglas, E. M., Mohn, B. M., \& Gushwa, M. K. The presence of maltreatment fatality-related content in pre-service child welfare training curricula: A brief report of 20 States. Child and Adolescent Social Work Journal. 2014; 32:213-218.

8. Loveleen K., Varadan S., Kumar P. Study on Child abuse: INDIA 2007. Ministry of Women and Child Development Government of India, 2007: 1-189

9. Putnam-Hornstein E, Wood JN, Fluke J, YoshiokaMaxwell A, Berger RP. Preventing severe and fatal child maltreatment: Making the case for the expanded use and integration of data. Child Welfare. 2013; 92(2):59-76.

10. Perez-Fuentes G, Olfson M, Villegas L, Morcillo C, Wang S, Blanco C. Prevalence and correlates of child sexual abuse: a national study. Compr Psychiatry 2013;54(1):16-27.

11. Humaira D, Rohmah N, Rifanda N, Novitasari $K$, Diena U, Nuqul FL. Kekerasan seksual pada anak: Telaah relasi pelaku subjek dan kerentanan pada anak. JPI 2015;12(2):5-10.

12. Whitaker DJ, Brenda LR, Karl H, Charlene KB, Pam MM, Gail R, Alisa K, Deborah DR. Risk factorfs for the perpetration of child sexual abuse: a review and meta-analysis. Child abuse \& neglect 2008; 32:529-48.

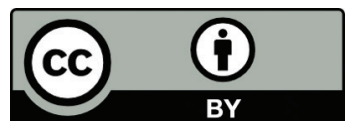

This work is licensed under a Creative Commons Attribution 